\title{
Populism, religion and family values policies in Israel, Italy and Turkey
}

Ben-Porat, Guy, Dani Filc, Ahmet Erdi Ozturk, and Luca Ozzano. "Populism, religion and family values policies in Israel, Italy and Turkey." Mediterranean Politics (2021): $1-23$.

Submitted: 11 December 2020

Accepted: 3 March 2021

Published Online: 29 April 2021

\begin{abstract}
There is a growing focus in political science on right-wing populist parties. But few comparative studies address their discourses and politics relating to family values, especially when involved with policy-making. Moreover, many comparative works about populism focus on a single region - often Western and Eastern Europe. This paper adopts a definition of populism with two different dimensions: the vertical (inclusive), which regards elites, and the horizontal (exclusive), which addresses 'foreigners'. The use of family values in political discourse and policy pertains to the two axes of populism. On the one hand are elites who are accused of being uncommitted to traditional values and morally corrupt. On the other hand are demographic concerns regarding declining birth rates among native populations and immigrants with large families. The stress on family values can also originate from a value orientation - or merely a tactical move - engendered by political competition. This paper specifically examines the politics of family values in the context of policies concerning gender equality, family planning and LGBT rights in three countries: Israel, Italy and Turkey. These countries share a rather strong religious tradition, experienced changes in family orientations and have populist political parties that appeal to religious values. In our comparative study, we explore these developments and the role of family values in the discourses and policies of the Likud and Shas parties in Israel, the Lega and Fratelli d'Italia parties in Italy and the AKP in Turkey.
\end{abstract}


Right-wing populist parties (RPP) have become prominent political actors across the world but relatively few comparative studies address their discourses and policies relating to family values and gender equality. Only lately, as Alessia Dona (2020) states, research has focused on the role gender plays in RPP's discourse and policies. RPP are associated with conservative values and affinity with religion. Accordingly, it is expected that they would oppose policies that favor LGBT+ rights and gender equality and support more traditional family values. Nevertheless, as we explore in this comparative study of RPPs in Italy, Israel and Turkey, these parties can display different and at times somewhat liberal attitudes towards these issues. These different attitudes, we argue in this paper, first, reflect particular relationships the parties maintain with religion. And, second, the "horizontal" distinction they wish to maintain between 'us' and 'them' (namely 'foreigners' or 'threatening others') can lead to a less conservative approach functional for strengthening this distinction.

While many comparative works about populism focus on a single region - often Western and Eastern Europe - a study of the Mediterranean can offer a different perspective. We adopt a definition of populism as related to two different axes: vertical, addressing "people" and elites, and horizontal, positing "people" against 'foreigners'. The use of family values in political discourse and policy pertains to both axes, with elites accused of being uncommitted to traditional values and morally corrupt, and demographic concerns regarding declining birth rates among native populations and immigrants with large families. In this paper, the politics of family values are studied through policies concerning gender equality, family planning and LGBT+ rights in three countries: Israel, Italy and Turkey. These countries share a rather strong religious tradition, but also experienced de-facto changes in family orientations and have populist political parties that appeal to religious values. In our comparative study, we explore these developments and the role of family values in the discourses and policies of the Likud and Shas parties in Israel, the Lega and Fratelli d'Italia parties in Italy and the AKP (Justice and Development Party- Adalet ve Kalkinma Partisi) in Turkey. 
In the first, theoretical, part of the paper, we explain the relation between RPPs, religion and family values, Then, in the second part, we describe our three case studies. Finally, we draw several insights from the comparison we make.

\section{Populism, Religion and Family}

Political scientists first identified the family of right-wing populist parties (RPP) in the 1980s and 1990s, when they emerged in European countries such as France, Italy and Austria (Ignazi 1994; Betz 1994). Since the 2000s, RPPs have become prominent not only in Europe as populist parties and leaders won elections in different countries, but also in other parts of the world such as the US, Brazil, and India (Marzouki, McDonnell, and Roy 2016; Albertazzi and Mcdonnell 2007; Minkenberg 2000; Brubaker 2017; Kriesi et al. 2008; Mudde 2007, Mudde and Rovira Kaltwasser 2013).

Populism has been defined as an ideology (Mudde 2007, Mudde and Rovira Kaltwasser 2017), a political strategy (Weyland 2001, Roberts 2006), a logic of politics (Laclau 2005), a mode of political practice (Jansen 2011) or a discursive style or frame (Jagers and Walgrave 2007, Moffitt and Tormey 2013, Aslanidis 2016). Although all these definitions can provide an explanation for the relationship between populism, religion and family values, we have chosen to adopt the 'ideational' definition of populism as most of the research on the topic (Abi Hassan 2017, de Lange and Mugge 2015, Spierings et al. 2015, Dietze and Roth 2020) do, namely:

... a thin-centered ideology that considers society to be ultimately separated into two homogeneous and antagonistic camps, "the pure people" versus "the corrupt elite," and which argues that politics should be an expression of the volonté Générale (general will) of the people (Mudde and Rovira Kaltwasser 2017, 6).

Moreover, studies of populism differentiate between "inclusionary" and "exclusionary" populism. The former suggests a vertical axis where the "people" (the 'plebs') are positioned against "elites". The latter, right wing populism, suggests a nativist understanding of the people as an ethno-cultural closed group, separating them from foreigners or outsiders (Betz 2001, Mudde and Katlwasser 2013). Populism, consequently, is 'an ideology which pits a virtuous and homogeneous people against a set of elites and dangerous "others" depicted as depriving (or attempting to deprive) the sovereign people of their rights, values, prosperity, identity and voice' (Albertazzi and Mcdonnell 2007, 3).

To Define the people negative contents - anti-elite or anti-foreigner - may not be enough. Accordingly, "populist politics also needs a convincing moral claim to trigger the 
self-righteous indignation necessary to construct, define and mobilise the authentic "good" people against the alien other' (Cohen and Arato, 2012: 102). Moreover, boundaries must be defined and maintained, because populism - particularly exclusionary right wing populism contains a strong friend/enemy logic, with elements of nativism and suspicion towards foreign ideas and people (Mudde, 2004: 16). In this context, religion can perform an important role in populist ideology and strategy by providing positive contents to the signifier "people", and a moral justification for it; and by delineating the boundaries of exclusion and inclusion. As Arato and Cohen illustrated,

Religious identity politics provide unifying content for the chain of equivalents in populist logic, helps moralize the friend and demonize the enemy, and to frame the elites and 'others' as immoral and corrupt, and thus part of a deeper threat to 'our' tradition that must be warded off, while providing a needed moral aura for populist politics (2012: 108).

The role that religion plays for RPPs, providing content and justification, explain the latter's association with religiosity, social conservatism and, consequently, support for 'traditional' family values. Accordingly, they are expected to oppose policies that promote gender equality and LGBT+ rights. But in many cases - mainly in the context of an anti-foreigners, and often anti-Islamic posture - RPPs adopt an identitarian 'Christianism', "a secularist posture, a philosemitic stance, and an ostensibly liberal defence of gender equality, gay rights and freedom of speech" that excludes non-European immigrants depicted as non-liberal and therefore foreign to European culture of tolerance (Brubaker, 2017.: 1193)[2].

Mudde and Rovira Kaltwasser (2015) argue that populist parties' attitudes regarding gender issues are unrelated to the core definition of populism. Comparing Latin American populism (Chavism and the Bolivian MAS) with Northern European RPPs they claim attitudes towards gender reflected the cultural milieu of each country (Latin American machismo vs more gender equal attitudes in Northern Europe) and the different parties' position on the left/right axis (left populists have more egalitarian stance than right wing populists). This view is shared Abi Hassan (2017) and Spierling (2020), who argues that gender does not belong to the core of radical right populism, but is "instrumentalized to ... emphasize [its] ideology" (Spierling 2020:42). Below, we offer a different explanation demonstrated through our case studies.

Conceptual approach and methodology:

Our conceptual approach is based on three main complementary arguments. First, against Mudde and Rovira Kaltwasser, we argue that right wing populist parties' approaches 
to family values and gender issues relate to the core definition of right wing populism. RPPs perceive the "people" as a big biological family, and the family as a gendered biological unity. This is not the case for other conservative parties, for which the people as a collective subject plays a lesser role; nor for left populist parties, who conceive the people inclusively. The right wing populist conception of the family includes a gender hierarchy (Collins 1998), and the traditional family is perceived as intrinsic to the definition of the people. Second, though the family is central to their conceptualization of the people, RPPs may adopt different attitudes and policy preferences towards gender- and family-related issues. This variance does not depend on their cultural milieu approach (pace Mudde and Rovira Kaltwasser's claim) but on two other variables. The first one, the particular relationships the parties maintain with religion, which determine their perceptions of family values and gender issues. The second one, whether a less conservative approach to family values and gender issues is functional to maintaining the horizontal distinction between "us" and "them", that is the main political issue for right wing populist parties.

Methodologically, the paper develops these two arguments through a comparative study of right-wing exclusionary populist parties in Israel, Italy and Turkey. In terms of the historical role of religion and the role of populist parties as key players in government, those are most-similar cases; while they differ in the religious traditions involved (Judaism in Israel, Christianity in Italy, and Islam in Turkey), and in patterns of relations and arrangements between religion and politics, with religion retaining different levels of authority and influence. The paper compares the following populist parties in the three countries: the Likud and Shas parties in Israel, the Lega and Fratelli d'Italia parties in Italy and the AKP in Turkey.

In the three cases below, we examine how the RPPs conceptualise their particular relations to religion and their approaches to issues of family and gender. Due to the limited scope of this paper we can only offer a conceptual idea through a glimpse of the different parties' positions, reflected in public debates and statements. As to the relation to religion, we consider the public significance of religious institutions - the Catholic Church, the Islamic Diyanet and the Rabbinical authority - and religious constituencies' impact on the parties' policies and platforms. We focus on two sets of policies where religious demands impact society at large, including non-religious, both related to "family values", which in all the cases we dealt with are crucial to define the boundaries between religion and state, and to give shape to debates between liberal and conservative values. Therefore, we examine, first, how the parties address issues of abortion and marriage, and second, their approaches to 
gender equality and LGBT+ rights. We analyse the parties' statements, platforms and policies to demonstrate similarities and differences and the circumstances under which they adopt conservative or relatively liberal attitudes.

\section{Israel}

Israel is considered the most family-oriented among post-industrial societies, having a high marriage rate, low divorce rate and high fertility rate (Fogel-Bijaoui, 2005). As elsewhere, religiosity strongly influences conservative attitudes towards family values, translating into opposition to abortion or same-sex marriage and a reluctance to support gender equality. Religion is integral to Israeli politics and social life, defining the boundaries of Jewish nationalism and impacting issues of citizenship and rights. The religious biological definition of a Jewish people - born to a Jewish mother - deeply influences the legal definition of citizenship. Debates over the status of halakhah (Jewish religious law) in the conduct of public and private life occupied the Zionist movement from its inception and produced a slew of compromises. The agreement that came to be known as 'status quo' was established prior to but was developed after - statehood in 1948 between the dominant and secular Labor party and the religious parties, guiding the role of religion in public life and including religious authority and monopoly over burial, marriage and divorce. Consensus around the status quo was depicted as essential for nation-building and allowed the Labor Party to dominate foreign policy and security in return for the religious Orthodox monopoly over significant aspects of public life, often at the expense of gender equality.

While religion remains a strong force in the Israeli society and has formally conceded little if any of its authority, it politicised religious-secular controversies, and undermined the consensus around the status quo. On the one hand, non-religious and liberal Israelis increasingly demand religious freedom and the end of the Orthodox monopoly. On the other hand, religious entities want to maintain what is described as the 'Jewish character of the state'. Liberal struggles for religious freedom in the 1990s were the consequence of two main nascent forces: the emerging market economy (Carmeli and Applebaum, 2006; Ram, 2008) and the mass immigration from the former Soviet Union of mostly secular Jews. Though these processes failed to alter formal laws and procedures, they did impact everyday issues such as sexuality and family life (Ben-Porat, 2013).

The religious public in Israel perceives the Orthodox monopoly on marriage as essential to maintain the unity of the people and prevent intermarriage. But the conservative nature of Israel's institutions on gender and family issues is matched by growing de-facto liberalisation. 
Secular Israelis who are increasingly discontent with the Orthodox monopoly found ways to evade restrictions, holding wedding ceremonies that matched their identity as secular Jews and their commitment to gender equality (Ben-Porat, 2013; Prashizky, 2011), married abroad or chose cohabitation (Glickman et al. 2003). This process of the de-institutionalisation of marriage also included demands for the state to recognise a growing number of alternative families and same-sex couples. Until the 1980s, homosexuality generally existed on the margins of society and was kept secret. But the struggle for equal rights intensified after the successful campaign to annul the law banning homosexual intercourse in 1988, emphasising the desire to integrate the LGBT+ community into Israeli society (Kama, 2000). The LGBT+ community entered the public dialogue via politics, courts of law, cultural creativity and the media. Same-sex relationships became increasingly legitimate, especially among the secular public, and annual gay pride parades began to be held even in more conservative cities such as Jerusalem. Norms changed and legal limitations were bypassed outside formal political institutions. But the next step - deemed essential to facilitate equal rights - was the struggle for the formal recognition of same-sex marriages and family units. Issues related to religious authority, gender equality and family values remain pertinent and incredibly politicised and relate to national unity and strength, forcing populist parties to take a stance.

Populism as a political phenomenon is central to Israeli politics, with two parties Likud and Shas - that have been a part of most governing coalitions for the past three decades. Likud, previously called Herut, became a populist inclusive movement under Menachem Begin's leadership (Filc 2010). The party developed a narrative of Israeli history that symbolically incorporated Mizrahim - Jews who immigrated from Arab countries - into the common 'we'. Incorporation was both material, through economic and social policies, and political, opening the party to a young Mizrahi leadership. The Likud is not a religious party but has a large traditional and even religious constituency and supports the status-quo. Since the mid-2000s, Likud has transformed into a populist exclusionary party, embracing nativism and, according to the religious definition of who is a Jew, emphasising a closed ethnonational unity based on 'common blood'.

Both Begin and Netanyahu, Likud's most salient populist leaders, conceived the [Jewish] people as a brotherhood. In one of his most famous discourses, Begin differentiated the Labor party's exclusion of Mizrahim from the Likud's approach, claiming "We are all brothers, all of us Jewish, all of us equal.” More recently, Netanyahu depicted this brotherhood as differentiating Jewish Israelis from Arabs and Palestinians: "[W]e must always remember a single, simple truth. We are brothers, we are one people, there is no other" (Netanyahu 2019). 
The people as brotherhood grounds an exclusive populism directed against the 'others'. As a result, the 'people' are described as constantly threatened by foreign enemies, Palestinian citizens or asylum seekers. Accompanying this is anti-elitism directed against the cultural and judicial elites, who are depicted as disloyal and favouring civil and human rights at the expense of national interests.

Shas emerged in 1983 as a reaction to the exclusion and segregation of the Mizrahim in the closed ultra-orthodox world and overall marginalization. The party's constituency comprises an ultra-orthodox core and a traditionalist periphery, the bulk of its voters are lowerclass Mizrahim (Peled, 1998). Shas addresses society as divided into the Jewish people ('we the people'), understood as a religious community, with Mizrahim as its core (the 'true' people). Like the Likud, Shas understands the people as a brotherhood, as its leader Arieh Deri tweeted after the September 2019 elections: "In this month of repentance and compassion, we must put hate behind us and remember that we [the Israeli Jews] are all brothers" Shas combines claims for Mizrahim's inclusion with support for exclusionary policies towards migrant workers and asylum seekers, though its approach to Arab citizens is more nuanced than that of Likud. As a religious party, it supports the primacy of Jewish religion, and its vision of democracy is profoundly anti-liberal. The party, representing the poor classes, also supports welfare policies and redistribution, another facet distinct from Likud's neo-liberal agenda.

Likud's exclusionary populism, directed against Arab citizens, asylum seekers and 'elites', accompanied a relatively liberal stance towards questions of family values and gender equality. The party adopted the status quo regarding marriage, opposing attempts to change the formal rules of marriage, but did little to prevent the growth of marriage outside the rabbinate, cohabitation and the de facto legalisation of alternative families. Similarly, Likud does not oppose abortion but did not join liberal demands to ease restrictions and make abortion completely voluntary. Its stance towards the LGBT+ community has largely been liberal: the party has an active LGBT+ forum, and one of its members, Amir Ohana, is a senior party member, former minister of justice and current minister of internal security and is openly gay. Likud formally supports gender equality and representation, but, like most other Israeli parties, women are a minority among party MKs and leadership. The party adopts 'feminist' policies in its active support for Arab women to enter the labor market such that 'feminism' becomes a way of stressing the differences between the (Jewish) people and the others, somewhat similar to what Brubaker (2018) describes for RPP's in Europe. Overall, Likud's moderate and liberal positions can be explained, first, because most its voters are not Orthodox religious, and, 
second, because these positions reinforce its populist-exclusionary approach to citizenship because they allow to present Muslims as "non-modern" and "non-tolerant."

For Shas, unlike Likud, family values are central. A 2006 survey demonstrated that Shas was far more committed to traditionalist values than Likud. This included its opposition to changing marriage legislation and to any recognition of LGBT+ families or extensions of LGBT+ rights (Shaham-Katzir 2006). Its leaders have been vocal against the LGBT+ community. For instance, when the Tel Aviv municipality included a gay couple in an advertisement, a Shas party member demanded its removal: "The municipality should strengthen family values rather than obscene massages' (Morag, 2013). They claimed that 'homosexuals poison society' and that legislation allowing gay couples to adopt children leads to 'Sodom and Gomorrah' (Wolff, 2008). A party member of Parliament was forced to resign after attending the wedding reception of his gay nephew. Party membership is restricted to men, since the party believes women should be kept away from public exposure, in general, and politics, in particular. Consequently, there are no women MKs, although the party organised women's meetings in the last elections to encourage women to vote. Shas opposes abortion, though it does not actively promote anti-abortion legislation.

In sum, both parties support the legal status quo, but Likud accepts informal liberalisation, and family values are not central to its agenda. Shas, conversely, views family values as paramount, and it actively supports the heteropatriarchy. Likud's 'exclusive populism', mostly wields religion instrumentally as a marker of a threat - Muslim enemies and their 'allies' among the liberal-secular left. For Shas, religion functions principally as the content of party identity and the foundation of Jewish-Mizrahi inclusion.

\section{Italy}

Although Italy is officially a secular state and Italian society has undergone significant secularisation processes in recent decades, Catholicism maintains a privileged role in the country in terms of societal and political influence (Garelli 2006; Diotallevi 2002). This influence is further enhanced by the morality politics mode of the Italian debate (Knill and Preidel 2015) and the Vatican's influence on centre-right and centre-left political actors (Ozzano 2015). This situation traditionally favoured conservative views on family- and genderrelated issues, which were partly shared, at least until the 1970s, also by many leftists and secular people. Particularly - while the views on gender roles largely changed between the 1970s and the 1980s, for example with the legalizations of abortion and divorce - it determined a broad consensus on the exclusion of LGBT+ rights from the field of legitimate issues of public discussion in Italy, and the tolerance of homosexual behaviours only insofar they 
remained purely private and hidden from public view. In the 2000s, and particularly the 2010s, this situation started to change, with an increasing public visibility of the LGBT+ community, and a growing number of Italians favourable to the public recognition of same-sex unions (with a slight majority in 2016, when the Italian parliament approved their legalization, which became almost $60 \%$, according to surveys, in 2020).

In this latter phase - with the Catholic Church increasingly focused on other social and economic issues under the leadership of Pope Francis - in the public discussion conservative positions on family issues and LGBT+ rights were largely shaped by two right-wing populist parties: the Lega (League) and Fratelli d'Italia (Brothers of Italy, FdI), which collectively won 21.7 per cent of the vote in the 2018 parliamentary elections and 40.7 per cent in the 2019 elections for the European Parliament.

The Lega, formerly Lega Nord (Northern League, LN), was created in 1989 with the coalescence of several northern Italian regionalist parties. Until the early 2000s, the party mostly focused on the centre-periphery cleavage, demanding autonomy - or even independence - for the northern Italian regions, and displayed an ambiguous attitude towards religion, with an oscillation between Christian ultra-conservative positions, and the use of neopagan symbols and rituals (Guolo 2011). The party's base, however, was markedly conservative and patriarchal, which involved conservative views on the family and gender roles and a restrictive idea of citizenship. Since the 2000s, the party has openly stressed a conservative Catholic identity, honing in on morality politics and religion-related issues, especially in opposition to religious pluralism and multiculturalism (Ozzano and Giorgi 2016; Ozzano 2016). This process culminated in 2013 with the leadership of Matteo Salvini, who successfully transformed the party into a full-fledged right-wing nationalist party, competing in all Italian regions and highlighting immigration as its main issue. This transformation of the party also implied the abandonment of neo-Pagan symbology, with a conservative view of Catholicism mainly indicative of a Western and Italian identity in opposition to Islam. In the late 2010s, this attitude culminated with Salvini's more explicit use of Christian symbols, particularly the crucifix, the Gospel and references to the 'Heart of Mary', during speeches at electoral rallies and even in parliamentary debates, a choice the Vatican itself criticised. In turn, the party did not refrain to harshly criticize the Church for its attitude towards immigration, Islam, and multiculturalism, regarded by the Lega as too soft (Passarelli and Tuorto 2018; Ozzano 2019 and 2020b; Molle 2019). 
FdI, unlike the Lega, is the heir to an extensive tradition of right-wing politics, which stems from the neo-fascist MSI. The party is rooted in a cultural tradition focused on an idea of citizenship conceived in ethnocultural - if not explicitly racist - terms, with a conception of the homeland and the Italian people as a wide family. In the early 1990s, the party carried out a process of internal revision and moderation and renamed itself Alleanza Nazionale (National Alliance, AN) before joining the Popolo della Libertà (People of Freedom, PdL) under Silvio Berlusconi's leadership (Ignazi 2018). In 2012, however, most former AN representatives decided to leave the PdL to form the FdI under the leadership of a woman: Giorgia Meloni. The supporters of the party, initially around 5 per cent, grew significantly in the late 2010s to well over 10 per cent.[4] In relation to religion, the party - although sharing with the Lega both the conservative platform and the conservative voting base - looked more restrained than this latter, both in terms of display of religious symbols and criticism towards the Church.

The positions of both parties towards family and gender-related issues are today marked by a conservative and identity-driven Catholic orientation, which aligns with the party's base that has always been quite morally traditionalist. Studies of the Lega carried out in the 2000s reported that Padania - the imagined northern Italian homeland that Lega militants sought to create - was conceived as 'a masculine nation' because of the idea of division of labour between genders, the machist attitude of the main LN leaders and an emphasis on toughness and courage in political activity (Scrinzi 2013, 5; Avanza 2008). However, the party frequently exploited the issue of women's rights and gender equality in relation to Islam and multiculturalism, especially in the 2000 s and 2010 s, when the party representatives sought to stigmatise the alleged superiority of Western culture in terms of civil rights and portray Islam as a threat to women's rights and integrity (Scrinzi 2012; Ozzano and Giorgi 2016).

These seemingly liberal cultural attitudes, however, were largely limited to the antiIslamic rhetoric, and often complemented a conspiratorial attitude, merging anti-leftist, Eurosceptic, anti-LGBT+ rights and pro-'traditional family' positions. In the 2000 s, the LN was crucial for the passage of law 40/2004, which strongly limited medically assisted procreation and stem cell research, and campaigned for the subsequent referendum, opposing its abrogation (Ozzano and Giorgi 2016). Party representatives were particularly outspoken on issues of LGBT+ rights, voicing their opposition to legalisation and deliberately employing politically incorrect language (Ozzano 2015; 2016) with homosexuals labelled as 'capons', 'culattoni' and 'finocchi' (Italian slurs).[5] For example, when Spain legalised same-sex marriage, the party dubbed La Padania "La favola di finocchio" (the fable of faggot).[6] The religious background of these statements was often implicit but was sometimes expressed 
openly. Minister for Reforms Roberto Calderoli, for instance, declared that the legalisation of same-sex unions 'makes me laugh. The good God made us with different qualities: man and woman.'[7]

The approach of the party to family and gender issues became more ambivalent in the 2010s. Its representatives - although not substantially changing their positions on these issues - mostly refrained from adopting the politically incorrect language their discourses were fraught with in the 2000s (Ozzano 2020a). Moreover, when the party formed a coalition government with the Movimento Cinquestelle (Five Star Movement - M5S) in 2018, Salvini proclaimed that issues, such as revising laws on abortion and same-sex unions, were not a part of the government program.

Conversely, the Lega managed to create a new Ministry of the Family and Disability, to which a member of his cadre, Lorenzo Fontana, was assigned. Fontana was known for being an ultra-conservative Catholic and a hardliner on issues of morality, as he made clear in interviews following his appointment.[8] In its defence of the traditional family, and in its engagement in the so-called anti-gender movement (Garbagnoli 2017; Prearo 2017), the party - now rebranded simply as Lega - also aligned and maintained frequent contacts with not only other European right-wing populist leaders but also international religious organisations and conservative groups from elsewhere in the world - particularly the US and Russia (which, although not directly engaged in politics, proposed platforms quite similar to right-wing populist parties). This became very clear in March 2019, when the World Congress of Families conference, a US Christian pro-life organisation with good ties with the former Soviet states, was held in Verona, Fontana's hometown and a hotbed of right-wing Catholicism.[9] Three Ministers of the Lega - Fontana, Salvini and Bussetti, the education minister - officially participated in the event, declaring their opposition to LGBT+ rights and criticising feminists, who, in Salvini's words, are unaware that the real danger their rights pose is 'Islamic extremism, a culture where the woman's value is less than zero' (Fox and Di Donato 2019). One of the event's organisers, the Lega Senator Simone Pillon, also submitted a contentious draft bill, which provoked harsh controversy among leftist groups and feminist and proposed a revision to the Italian family law, particularly for the regulations on the custody of minors (Lavizzari 2019).

FdI's positions have not been subjected to extensive academic analysis, both because the party's electoral support was, until 2019, quite limited, and because its positions are rather similar to Lega's platform (Ignazi 2018). This is particularly true for issues of religion and morality politics, with the party opposing multiculturalism, the immigration of Muslims and 
the construction of mosques (Ozzano and Giorgi 2016) and sometimes waving the flag of religious freedom to push an anti-Islamic perspective, as its members did in April 2019 after the bloody jihadist attacks in Sri Lanka. This position also relates to a support for Chauvinist welfare measures, in line with the traditional 'social' orientation of the Italian post-Fascist and neo-Fascist far right. The party supports the idea of the 'traditional family', although its opponents have criticised Giorgia Meloni, as they did with Salvini, because this position apparently contradicts the choices in her private life. With gender issues, the party, like the Lega, has joined in the 2010s the chorus of conservative Catholic and right-wing groups denouncing an alleged gender conspiracy, and Meloni also participated in the World Congress of Families in Verona (Garbagnoli 2017; Pavan 2019). Constituting one small distinction between the two parties, perhaps, is Meloni's image of being a publicly engaged woman, similar to France's Marine Le Pen, emphasising the inclusion of women in the workforce and messages explicitly addressed to women (Nadeau 2018) which have appeared less frequently in Lega's communications. On the other hand, Meloni, unlike other Italian female centre-right politicians, has consistently supported a resolutely pro-life platform by, for example, endorsing a pro-life motion approved by the City Council of Verona and supporting the pro-life association ProVita, which had affixed an anti-abortion poster depicting a fetus in Rome.[10]

As a whole, both parties propose an exclusionary version of populism and a traditionalist agenda in relation to gender and morality issues, although both of them are increasingly ambivalent in their rhetoric (often in anti-Islamic perspective) and have adopted in the 2010s a more politically correct language. In the case of the Lega, the conservative platform is more explicitly framed in religious terms, with the uninhibited use of Christian symbols at political rallies and, apparently, the attempt to compete with the Vatican to define the meaning of Christianity in the public sphere.

\section{Turkey}

In modern Turkey, religion has always occupied a unique and salient role in both state and society, lying somewhere between the mutually dependent points of continuity and disengagement, and the boundaries of legitimacy these designated (Ozturk 2021, Kuru 2009). Although the state has been defined as constitutionally secular, religion remained significant, though in different institutions and communities which have direct or indirect relations with the state (Ozturk 2019). This sui generis state-religion relations and the constitutional secularism had significant implications for women (White 2003), who earned the right to vote and be elected to office much earlier than in many Western nations. A series of laws passed since 1930 allowed women to participate in municipal elections and later to be muhtars 
(leaders) in villages and to be elected to village councils of elders (Arat 1989, 29). They gained the rights to vote for and be elected parliamentary deputies with legislative changes made in the Constitution and in the Elections Law on 5 December 1934 (Arat 2000). Yet gender equality was limited and instrumental in Turkey's Islamist political parties (Kadioglu 1994, 645), communities and institutions, all of which operated within a patriarchal order (Kandiyoti 1991). The Diyanet, for example, can nominate women employees and offers separate services to women with religious personnel called vaize (Maritato 2015), but its overall attitude remains conservative via employing patriarchal language. Even though, during the progressibe years the AKP committed not to follow classical Islamist road, as of 2021, the party has been using overdoes Islam almost in every political move, including gender equality, family planning and LGBT+ rights.

The AKP's rise to power included an implicit populist horizontal distinction of us/them between secular city-dwellers (the so-called white Turks) and the more religious Turkish citizens of the province (Yilmaz 2017). The party, through religious groups and communities, mobilized support that enabled it to become the ruling party. Under AKP rule, religion and religious communities became ever more important, part and parcel of the party's populism. Religious oriented policies received support from significant constituencies (Kaya 2015), but sharpened divisions within society. In this regard, some have argued that the AKP's populism has been nourished by Islamic discourse (Yabanci 2020), and the AKP's populism can be defined as both inclusive, against secular elites, and exclusive, instrumentalising ethnoreligious based nationalism against the West and non-Muslims (Yabanci 2018; Yalvac and Joseph 2019). These ideas were not directly present in the early years of the AKP's rise to power, but over time, the party adopted an explicit nativist (mainly anti-Kurd and anti-Alevi) and authoritarian stance, with direct bearing on family and gender issues (Cosar and Yegenoglu 2011), and a unique version of religious populism.

Positioning itself as a 'catch-all party' (Çınar 2016) enabled the AKP to receive support from wide cycles. Its inclusive populism was directed against the bureaucratic establishment (Gursoy 2019) and the Kemalist elites. This allowed it to garner sympathy from liberal and leftist groups, who sought to be rescued from military and bureaucratic tutelage, the lowermiddle class, which supported market economics in expectation of upward mobilisation, and moderately religious citizens. Accordingly, the AKP collaborated with various segments of society and earned support while doing so. Apart from a few exceptions, which associated themselves with classical centre-right parties, nearly all Islamic community organisations ultimately became supporters of the AKP, including the controversial Gülen Movement. 
Indeed, this kind of division should be seen as the beginning of polarisation and criminalisation of the opponents even in the Party's progressive years.

After the first decade of 2000's, global and regional developments - particularly the Arab spring - declining economic growth, internal instability and the Gezi Park demonstrations in 2013, and the conflict with the Gülen Movement - triggered changes (Watmough and Ozturk 2018). Changes made AKP's populism more inclusive, drawing support from the masses, and exclusive, further emphasising the role of nationalism. The AKP's authoritarian drift created a party structure loyal to its leader from bottom up and under his control (Yabanci 2020). Under this growing authoritarianism that AKP also withdrew from the relatively liberal stance of its early period. Party's rhetoric and policies were directed against civil society organisations, including those working to promote gender equality (Gunes-Ayata and Dogangun 2017). This change can be described as the party's return to its Islamic foundations, a male-dominated understanding of politics and an exclusive populist discourse against non-Sunni Muslims. The shift to authoritarianism under the AKP - and the unification of this authoritarianism with Islam - meant that religion was used to draw moral boundaries, with family values and gender issues defining a moral community (Mutluer 2019). In this community, being a member of an Islamic organisation is a dominant component of the definition of a big family in the mindset of the AKP regime, partitioning 'us' from 'them' along the fault lines of gender and family issues. Here, as in the previous two cases, nation and family became intertwined.

After taking power, Erdoğan emphasised that LGBT+ rights, women equality and freedoms would be legally guaranteed, but his stance and the party's, became gradually more authoritarian and conservative, illustrated by the actions and statements of AKP administrators and parliamentary members. The party's MPs, for example, objected to the inclusion of LGBT+ citizens and rejected the proposal to create a 'Branch Directorate for Social Gender Equality' in the opposition-held Istanbul Metropolitan Municipality. During the Istanbul Metropolitan Municipal Assembly's second session, in March 2020, AKP member of parliament Kaynar stated that 'social gender' addressed an 'intermediary gender' rather than men and women. Unwilling to say 'LGBT+', he instead just mentioned 'those letters':

Social gender equality is not a concept relating to women. They are trying to deceive the public by concealing something here. The creation of this directorate is the defence of those letter. There have been a few attempts by the LGBTs in Istanbul that have failed. They want to enact a slew of things, wrapping themselves in the colours of the 
rainbow. They are now trying to enact this with the municipality, and we oppose this politically, culturally and religiously.[11]

In earlier years, when EU accession was still discussed, the AKP was ambivalent about questions such as the criminalisation of adultery and extra-marital sex (zina in Islamic law) and the legalisation of abortion. Under the new populist stance, however, its position crystallised and became more conservative. Erdoğan, who at every opportunity during his tenure as prime minister articulated his opposition to caesarean births and abortion, encouraged Turkish families to have three children for the sake of cultivating future religious generations in order to protect the country's legacy. Furthermore, femicide experienced a drastic spike in Turkey during AKP rule, which was marred with masculine politics. The recommendations of the family and religious guidance bureaus, part of the Diyanet, to combat violence against women were very conservative and misguided. They suggested that women who suffer violence from men examine their own behaviours, attempt to resolve the dispute within the family and appeal to authorities only as a last resort. Contradicting the spirit of the Istanbul Convention, which aims to eliminate gender-based violence and to which Turkey is a party, Turkey and the Diyanet have adopted a more conservative approach. The messages the Diyanet has released for women feature concepts such as 'emanet', 'itaat' and 'fitrat' (security, obedience and motherhood), while equality was notably absent.

Traditional gender roles were portrayed as moral and essential for the strength of the nation. On International Women's Day in 2016, Erdogan said he believes that 'a woman is above all a mother' and urged the audience to protect family rights as Islam commands. He underlined that one cannot free women by destroying the notion of family, drawing on references from Quran.[12] Similarly, he argued that Muslim families should forgo birth control and that abortion is a crime against humanity that is polarising Turkish society.[13] Finally, Erdogan openly declared, in 2014, that equality between men and women violates nature: 'You cannot make a mother, who must breastfeed her child, equal to a man. You cannot make women do everything men do, as the communist regimes did ... this is against her delicate nature.'[14]

The AKP regime, by combining moral, religious and family values, severed the 'virtuous-Muslim' (us) from the 'immoral-deviant' (others). Its religious and anti-elitist discourse targeted the Kemalist secular elite - founders of modern Turkey - positing devout Anatolians as the 'people', pious and loyal. In late 2018, for example, Erdogan labelled the Kemalists "parasites": 'Elites who leech off of the country, eat the creams of this country, they 
are the main reason for cultural loss.'[15] He also blamed the Turkish secular elite for the marginalisation of the devoted masses' moral values, and condemned attempts to secularise them. He frequently stressed that the Turkish people must uphold their moral values and maintain their lifestyles according to the principles of Islam.[16] On January 1, Erdogan appointed a controversial new rector for Bogazici University, one of Turkey's prestigious universities. Students and academic staff protested the nomination, described as "political." Police arrested five students during the protest after an art exhibition included an LGBT flag alongside the Kaaba, a sacred Muslim site. Erdogan accused LGBT+ activists of undermining 'our national and spiritual values' and 'poisoning' young people. [17]

Overall, the AKP has shifted from its inclusive and relatively liberal stance into a rightwing populist party, attached to its religious core. Religiosity was inseparable from AKPs populism, leaving little room for liberalism. Consequently, family values and tradition, according to the AKP, separated the "people" from elites, polarizing Turkish society.

\section{Concluding Remarks}

Studies of populism adopt different points of view about whether family and genderrelated issues are at the core of populist ideology, and which factors explain populist parties and leaders' stances on those issues. Mudde and Rovira Kaltwasser's claim that family and gender issues are not central to populist conceptions and that the dominant conceptions about these issues in specific countries determine the attitudes of populists. In this paper, we offer a different explanation. Drawing on the case studies presented above we argue that family and gender issues are central to exclusionary populism because "the people" are conceived as a broad family. Moreover, we argue that it is not the 'national culture' but the role played by religion in a party's ideology that is the leading factor in determining that party's attitude towards family and gender issues. In other words, exclusionary populist parties that are not explicitly religious can display a more liberal attitude towards in-group members, presenting vertical and horizontal dimensions. The nativist understanding of the people - as an ethnocultural closed group positioned against the threat of 'others' - signifies, primarily, that LGBT+ individuals can be respected and regarded as group members. Second, in-group tolerance is presented as a virtue that separates them from the intolerant 'others'. And third, issues of family values and gender equality can be perceived as secondary to combatting the threats of 'outsiders/others'.

The two Israeli populist parties share some commonalities but differ in their approaches to family and gender issues. Overall, family issues are central to Israeli populism, since blood ties define belonging to the people (Jewishness based on matrilineal descent). However, it is 
the degree of religiosity rather than the broader national context that explains how populist parties address questions of gender equality, abortion and LGBT+ rights. Shas, a steeply religious party, displays the expected conservative position: strong opposition to LGBT+ rights and reluctance to accept ideas and demands for gender equality. Conversely, Likud, a party with a broader base of support that includes many traditional rather than religious Jews, displays a more liberal attitude towards issues of family values and gender equality. This somewhat liberal approach, however, is limited to in-group members and is matched by growing intolerance towards Arab citizens and asylum seekers. In the case of Likud and Shas, therefore, exclusionary populism can draw different boundaries between us and them, either conservative and based on religion, or broader and simultaneously liberal (towards the ingroup) and illiberal.

As in Israel, the two Italian parties this paper discussed are both similar and dissimilar. It is clear that family and gender issues are not incidental but are at the core of messages in the discourses of the right-wing populist parties. For FdI, this is congruent with its neo-fascist roots, focused, as its main tenets, on the defence of the national community and the 'traditional' family. A somewhat distinct ideological path appeared for the Lega as well as a deep resonance between conservative positions on gender and family-related issues and the party's traditional patriarchal and machista culture. The connection between these positions and religious values was often made explicit in both cases. The Lega's current leader, Salvini, appears intent on striking a balance between a pro-religious orientation, which has recently acquired a peculiar and devotional tone, and a partial downplaying of morality issues in favour of a main focus on immigration and 'Chauvinist' welfare. In this context, immigrants are the main targets of stigmatisation and of the boundaries drawn between 'us' and 'them'. Under these circumstances, LGBT+ people are sometimes presented as the promoters of an alleged 'gender conspiracy', which is lowering Italy's birth rate and decimating the 'traditional' family. But in other cases - in what largely appears to be a strategic if not utterly opportunistic discourse they are cautiously portrayed as rights holders, especially when the stigmatisation of Islam and its alleged backwardness and intolerance are at stake. On the other hand, FdI - although sharing most of the Lega's platform, grounds its positions on its more traditional conservative Christian roots, and has sometimes displayed more outspoken positions, for example in its opposition to abortion. In this case, the openings on family- and gender-related issues are mostly related to the party's female leader Meloni who - like Marine Le Pen in France's Rassemblement National party - proposed a model of engaged woman which is partly unconventional for conservative right culture. 
Finally, the AKP in Turkey is a religious party in a Muslim-majority country whose perceptions towards gender equality and family values are compatible with Mudde and Kaltwasser's claims. Erdoğan's and the AKP's approaches to gender and family-related issues combine a populist, nativist understating of the people with a religious conservative mind-set. The AKP's exclusionary populism, which aims to biologise the 'Turks', stresses the roles of shared blood, cultural patterns and history that sets the Turks apart from others. As a religious party, seeking to push back Turkey's secularisation, however, the AKP also displays particular conservative attitudes towards questions of gender equality and LGBT+ rights. The traditional family and traditional gender roles are central to the party's platform. The AKP government, growing more authoritarian, made social transformation a goal, adopting religion and a maledominated language and policy as a base for social cohesion. Somewhat like that of Shas, this exclusivist populism depicts the secular elites, previously in power, as the 'other' against the people, devout Muslims committed to religious values.

Our comparative study of three cases and five parties, challenges Mudde and Kaltwasser's claim that family and gender issues are marginal for populist parties and that these parties' approaches to gender relies on the characteristics of specific national culture. First, the conception of the people as a traditional family is central to the nativist definition of the people and to the constitution of the boundaries separating 'us' from 'them'. Exclusionary populism 'biologises' the people, stressing the role of 'shared blood' as what defines the unified people. A relationship exists between the idea that the 'flow of blood' regulates rights and the conception of the family as a gender hierarchy (Collins 1998). The traditional family is the more elemental unification of the people, understood as the sameness of blood. Moreover, a certain degree of tolerance is instrumental to the exclusion of the Muslim 'other', as is the case for Lega and Likud, using (in-group) liberalism to demarcate boundaries.

Secondly, as the three cases demonstrate - but this is most salient for the AKP in Turkey and Shas in Israel - it is the articulation of populism with religion more than the specific national culture that explains the adoption of conservative family values as well as malechauvinist and anti-LGTB+ attitudes and policies. In our view, the analysed cases show that RPPs approach to family and gender stems from the combination of nativism and religion. When the role of religion is more vague, parties can adopt relatively open positions on family and gender issues, especially when a comparison with other cultures, regarded as backward, is at stake. Parties whose ideology is imbued with religious values stick more closely, in their positions and policies, to a conservative and restrictive view of family and gender issues. 


\section{Bibliography}

Abi Hassan Sahar, 2017, "Populism and Gender", in Rovira Kaltwasser C. et al (eds), The Oxford Handbook of Populism, Oxford: Oxford University Press.

Albertazzi, Daniele, and Duncan Mcdonnell. 2007. "Introduction: The Sceptre and the Spectre." In Twenty-First Century Populism: The Spectre of Western European Democracy, edited by Daniele Albertazzi and Duncan Mcdonnell, 2007th ed., 1-11. Houndmills, Basingstoke, Hampshire England; New York: Palgrave Macmillan.

Arat, Yesim, 2000, "Gender and citizenship in Turkey." Gender and citizenship in the Middle East: 275-86.

Arat, Yeşim. 1989, The patriarchal paradox: Women politicians in Turkey. Fairleigh Dickinson Univ Press.

Aslanidis Paris, 2016, "Is Populism an Ideology? A Refutation and a New Perspective", Political Studies 64:88-104.

Avanza, Martina. 2008. “Un Parti Qui 'l'a Dure'. Les 'Femmes Padanes' Dans La Ligue Du Nord.” In Le Sexe Du Militantisme, edited by Olivier Fillieule and Patricia Roux, 14366. Paris: Presses de Sciences Po.

Ben-Porat, Guy. 2000. "In a State of Holiness; Rethinking Israeli Secularism,” Alternatives 25(2): 223-246.

Ben-Porat, Guy. 2005. "Netanyahu's Second Coming? A Neoconservative Policy Paradigm." Israel Studies 10(3): 222-45.

Ben-Rafael, Eliezer. 2007. "Mizrahi and Russian Challenges to Israel's Dominant Culture: Divergences and Convergences," Israel Studies 12(3): 68-91.

Betz, Hans-Georg. 1994. Radical Right-Wing Populism in Western Europe. Springer.

Brubaker, Rogers. 2017. "Between Nationalism and Civilizationism: The European Populist Moment in Comparative Perspective.” Ethnic and Racial Studies 40 (8): 1191-1226.

Caplan, Kimmy. 2007. Internal Popular Discourse in Israeli Haredi Society. Jerusalem: Shazar Center (Hebrew).

Cinar, Kursat, 2016, "Local determinants of an emerging electoral hegemony: The case of Justice and Development Party (AKP) in Turkey." Democratization 23, no. 7: 121635.

Coşar, Simten, and Metin Yeğenoğlu. 2011 "New grounds for patriarchy in Turkey? Gender policy in the age of AKP." South European Society and Politics 16(4) :555-573. 
de Lange Sarah \& Mügge Liza, 2015, Gender and right-wing populism in the Low Countries: ideological variations across parties and time, Patterns of Prejudice, 49:61-80.

Dietze Gabriele and Roth Julia, 2020, Right-Wing Populism and Gender: A Preliminary Cartography of an Emergent Field of Research, in Dietze and Roth (eds) Right-wing Populism and Gender, Bielefeld: transcript Verlag.

Diotallevi, Luca. 2002. "Internal Competition in a National Religious Monopoly: The Catholic Effect and the Italian Case." Sociology of Religion 63 (2): 137-55.

Dona Alessia, 2020, "What's Gender Got to Do With populism?", European Journal of Women's Studies, 27: 285-292.

Elam, Yigal. 2000. Judaism as a Status Quo. Tel-Aviv: Am Over (Hebrew).

Fogiel-Bijaoui, Sylvie. 2005. "Families in Israel: Post Modernity, Feminism and the State," in J. L. Roopnarine and U. P. Gielen (eds.), Families in Global Perspective. Boston: Allyn \& Bacon, pp. 184-204.

Font, Nuria, Paolo Graziano, and Myrto Tsakatika. 2019. "Varieties of Inclusionary Populism? SYRIZA, Podemos and the Five Star Movement." Government and Opposition, 1-21. Fox, Kara, and Valentina Di Donato. 2019. “In Italy's City of Love, Global Far-Right Groups Join Forces under a 'pro-Family' Umbrella.” CNN. March 31, 2019. https://www.cnn.com/2019/03/31/europe/verona-world-congress-of-familiesintl/index.html

Garbagnoli, Sara. 2017. "Italy as a Lighthouse: Anti-Gender Protests between the 'Anthropological Question' and National Identity." In Anti-Gender Campaigns in Europe: Mobilizing Against Equality, edited by Roman Kuhar and David Paternotte. London; New York: Rowman \& Littlefield International.

Garelli, Franco. 2006. L'Italia cattolica nell'epoca del pluralismo. Bologna: Il Mulino.

Güneş-Ayata, Ayşe, and Gökten Doğangün. 2017 "Gender politics of the AKP: Restoration of a religio-conservative gender climate." Journal of Balkan and Near Eastern Studies 19(6): 610-627.

Guolo, Renzo. 2011. Chi impugna la croce. Lega e Chiesa. Roma / Bari: Laterza.

Ignazi, Piero. 1994. L'estrema destra in Europa. Bologna: Il Mulino.

Ignazi, Piero. 2018. I partiti in Italia dal 1945 al 2018. Bologna: Il Mulino.

Jager Jan and Walgrave Stefaan, 2007, "Populism as a Political Communication Style", European Journal of Political Research 46: 319-345.

Jansen Robert, 2011, 'Populist Mobilization: A New Theoretical Approach to Populism', Sociological Theory, 29: 75-96. 
Kadioğlu, Ayşe. 1994 "Women's subordination in Turkey: Is Islam really the villain?." The Middle East Journal: 645-660.

Kaltwasser, Cristobal Rovira, Paul A. Taggart, Paulina Ochoa Espejo, and Pierre Ostiguy, eds. 2018. The Oxford Handbook of Populism. Oxford; New York: Oxford University Press. Kama, Amit. 2000. "From Terra Incognita to Terra Firma: The Logbook of the Voyage of Gay Men's Community into the Israeli Public Sphere," Journal of Homosexuality 38(4): $133-62$.

Kandiyoti, Deniz. 1991. "End of empire: Islam, nationalism and women in Turkey." In Women, Islam and the state, pp. 22-47. Palgrave Macmillan, London.

Kaya, Ayhan. 2015. "Islamisation of Turkey under the AKP rule: Empowering family, faith and charity." South European Society and Politics 20, no. 1: 47-69.

Kyle Jordan and Gultchin Limor, 2018, Populists in Power Around the World, London: Tony Blair Institute for Global Change.

Knill, Christoph, and Caroline Preidel. 2015. "Institutional Opportunity Structures and the Catholic Church: Explaining Variation in the Regulation of Same-Sex Partnerships in Ireland and Italy." Journal of European Public Policy 22 (3): 374-90.

Kriesi, Hanspeter, Edgar Grande, Romain Lachat, Martin Dolezal, Simon Bornschier, and Timotheos Frey. 2008. West European Politics in the Age of Globalization. Cambridge, UK ; New York: Cambridge University Press.

Kuru, Ahmet T. 2009. Secularism and state policies toward religion: The United States, France, and Turkey. Cambridge University Press.

Laclau, Ernesto. 2005. On Populist Reason. New York: Verso.

Lavizzari, Anna. 2019. Protesting Gender: The LGBTIQ Movement and Its Opponents in Italy. Routledge.

Marin, Yuval. 2004. "The Right to Family Life and Civil Marriage under International Law and Its Implementation in the State of Israel," Bepress Legal Series, Paper 275.

Maritato, Chiara. 2015. "Performing Irşad: Female preachers'(vaizeler's) religious assistance within the framework of the Turkish state." Turkish Studies 16, no. 3: 433-47.

Marlow, Louise. 2002. Hierarchy and egalitarianism in Islamic thought. Cambridge University Press.

Marzouki, Nadia, Duncan McDonnell, and Olivier Roy, eds. 2016. Saving the People: How Populists Hijack Religion. Oxford; New York: Oxford University Press.

Minkenberg, Michael. 2000. "The Renewal of the Radical Right: Between Modernity and Antimodernity." Government and Opposition 35 (2): 170-88. 
Moffitt, Benjamin and Tormey, Simon 2014 'Rethinking Populism: Politics, Mediatisation and Political Style', Political Studies, 62: 381-97.

Molle, Andrea. 2019. "Religion and Right-Wing Populism in Italy: Using 'Judeo-Christian Roots' to Kill the European Union." Religion, State and Society 47 (1): 151-68.

Morag Gilead. 2013. Dan and Dani Hold Hands: Shas Against Tel Aviv Municipality, https://www.ynet.co.il/articles/0,7340,L-4344744,00.html (Hebrew).

Mudde, Cas, and Cristóbal Rovira Kaltwasser, 2013, "Exclusionary Populism and Inclusionary Populism: Comparing Contemporary Europe and Latin America", Government and Opposition 48: 147-174.

2017, Populism a Very Short Introduction,

Oxford: Oxford University Press.

Mutluer, Nil. 2019 "The intersectionality of gender, sexuality, and religion: Novelties and continuities in Turkey during the AKP era." Southeast European and Black Sea Studies 19, (1):99-118.

Nadeau, Barbie Latza. 2018. "Femme Fascista: How Giorgia Meloni Became the Star of Italy’s Far Right." World Policy Journal 35 (2): 14-21.

Netanyahu Byniamin, 2019, https://www.ynet.co.il/articles/0,7340,L-5527146,00.html, last entered 16/11/20202.

Öztürk, Ahmet Erdi. 2019. "An alternative reading of religion and authoritarianism: the new logic between religion and state in the AKP's New Turkey." Southeast European and Black Sea Studies 19, no. 1: 79-98.

Öztürk, Ahmet Erdi. 2021. Religion, Identity and Power: Turkey and the Balkans in the Twenty First Century. Edinburgh: Edinburgh University Press.

Ozzano, Luca and Chiara Maritato. 2019. "Patterns of political secularism in Italy and Turkey: the Vatican and the Diyanet to the test of politics.” Politics and Religion 12, no. 3: 45777.

Ozzano, Luca, and Alberta Giorgi. 2016. European Culture Wars and the Italian Case: Which Side Are You On? London: Routledge.

Ozzano, Luca. 2015. “The Debate about Same-Sex Marriages/Civil Unions in Italy’s 2006 and 2013 Electoral Campaigns." Contemporary Italian Politics 7 (2): 144-60.

Ozzano, Luca. 2016. "Two Forms of Catholicism in Twenty-First-Century Italian Public Debate: An Analysis of Positions on Same-Sex Marriage and Muslim Dress Codes." Journal of Modern Italian Studies 21 (3): 464-84. 
Ozzano, Luca. 2019. "Religion, Cleavages, and Right-Wing Populist Parties: The Italian Case." The Review of Faith \& International Affairs 17 (1): 65-77.

Ozzano, Luca. 2020a. "Last but Not Least: How Italy Finally Legalized Same-Sex Unions." Contemporary Italian Politics 12 (1): 43-61.

Ozzano, Luca. 2020b. The Masks of the Political God. Religion and Political Parties in Contemporary Democracies. Lanham: Rowman and Littlefield.

Passarelli, Gianluca, and Dario Tuorto. 2018. La Lega di Salvini. Estrema destra di governo. Bologna: Il Mulino.

Patton, Marcie J. 2006. “The economic policies of Turkey’s AKP government: Rabbits from a hat?." The Middle East Journal 60, no. 3: 513-36.

Pavan, Elena. 2019. "Il Movimento va al Congresso. Reti di movimenti anti-gender tra dispositivi retorici, partecipazione dal Basso, conoscenza e alleanze politiche." Polis, no. $2 / 2019$.

Peled, Yoav. 1998. "Towards a Redefinition of Jewish Nationalism in Israel? The Enigma of Shas," Ethnic and Racial Studies 21(4): 703-27.

Prashitzky, Ana. 2011. "The Construction of Collective Memory in the Realm of Orthodox and Alternative Jewish Marriage Ceremonies,” Megamot 48(1): 86-108 (Hebrew).

Prearo, Massimo. 2017. "Le cadrage religieux de la mobilisation «anti-genre» : une étude micro-événementielle du Family Day." Genre, sexualité \& société, no. 18 (December).

Ram, Uri. 2008. The Globalization of Israel: McWorld in Tel-Aviv, Jihad in Jerusalem. New York: Routledge.

Roberts Kenneth, 2006, "Populism, Political Conflict and Grass-roots Organization in Latin America", Comparative Politics 38: 127-148.

Rooduijn, Mattijs, Van Kessel, Stijn, Froio, Caterina, Pirro, Andrea, De Lange, Sarah, Halikiopoulou, Daphne, Lewis, Paul, Mudde, Cass. \& Taggart, Paul. 2019. The PopuList: An Overview of Populist, Far Right, Far Left and Eurosceptic Parties in Europe. www.popu-list.org.

Rynhold, Jonathan. 2002. "In Search of Israeli Conservatism.” Journal of Political Ideologies, 7(2): 199-220.

Scrinzi, Francesca. 2012. “Gendering Anti-Immigration Politics in Europe.” Queries, no. 1 (7): 79-90.

Scrinzi, Francesca. 2013. "Women's Activism and Gender Relations in the Northern League (Lega Nord) Party." Paper presented at the ECPR General Conference, Bordeaux, 
September. https://ecpr.eu/filestore/paperproposal/98713d12-5c1e-484c-8c74490ed670cd02.pdf

Shaham-Katzir Lilah. 2006. Examining Parties: Marriage and Divorce, https://www.ynet.co.il/articles/0,7340,L-3223909,00.html) (Hebrew).

Spierings Niels, 2020, "Why Gender and Sexuality are both Trivial and Pivotal in Populist Radical Right Politics", in Dietze and Roth (eds) Right-wing Populism and Gender, Bielefeld: transcript Verlag.

Spierings Niels, Zaslove Andrej, Mügge Liza \& de Lange Sarah. 2015. Gender and populist radical-right politics: an introduction, Patterns of Prejudice, 49:3-15

Tessler, Ricki. 2003. In the Name of the Lord: Shas and the Religious Revolution. Tel-Aviv: Keter (Hebrew).

Watmough, Simon P., and Ahmet Erdi Öztürk, 2018. "The future of the Gülen Movement in transnational political exile: introduction to the special issue." Politics, Religion \& Ideology 19 (1): 1-10.

Weyland Kurt, 2001, "Clarifying a Contested Concept: Populism in the Study of Latin American Politics", Comparative Politics 34: 1-22.

White, Jenny B. 2003. "State feminism, modernization, and the Turkish republican woman." NWSA Journal: 145-59.

Wolff Pinhas. 2008. Benizri: Homosexuals are Responsible for the Earthquakes, https://news.walla.co.il/item/1237361 (Hebrew).

Yabanci, Bilge. 2020. "Fuzzy Borders between Populism and Sacralized Politics: Mission, Leader, Community and Performance in 'New'Turkey." Politics, Religion \& Ideology 21 (1): $92-112$.

Yilmaz, Zafer. 2017. "The AKP and the spirit of the 'new'Turkey: Imagined victim, reactionary mood, and resentful sovereign." Turkish Studies 18 (3) : 482-513.

[1] For a review of the main theoretical perspectives and definitions, see (Mudde and Rovira Kaltwasser 2017). 
[2] Moreover, right-wing populism's attachment to religion can be rather loose or instrumental and adopt a liberal stance - limited to the in-group - under certain conditions of perceived external threat and in countries that have undergone secularisation.

[3] With the exception of Shas party, all the other parties are included in the Institute of Global Change's Populist in Power Around the World (Kyle and Gultchin 2018), or in the PopuList (Roodjuin et al. 2019).

[4] See, for example, https://www.youtrend.it/2020/03/27/supermedia-sondaggi-politici-26marzo-lega-sotto-il-29/ (accessed 24 July 2020)

[5] See, for example, La Stampa, 1 July 2005; La Padania, 22 September 2005; and Il Corriere della sera, 18 June 2006.

[6] La Padania, 25 April 2005

[7] La Repubblica, 4 Sept. 2005

[8] See, for example, Il Corriere della sera, 2 June 2018. https://www.corriere.it/politica/18_giugno_02//orenzo-fontana-famiglie-gay-non-esistonoora-piu-bambini-meno-aborti-abc3cae2-65d4-11e8-b063-cd4146153181.shtml (accessed 15 $\underline{\text { July 2020) }}$

[9] http://profam.org/

[10] See these articles from FdI's official website:_https://www.fratelliitalia.it/2018/10/06/aborto-meloni-le-fatwe-di-bonino-e-co-non-ci-fanno-paura/ $\quad$ and https://www.fratelli-italia.it/2018/04/07/aborto-meloni-comune-roma-e-m5s-imbavaglianonoi-pubblichiamo-il-manifesto-sui-social/ (accessed 19 July 2020) https://www.kaosgl.org/haber/gokkusagi-renklerine-burunulerek-birtakim-seyleryapilmak-istendi (accessed 21 March 2020).

[12]_ https://www.theguardian.com/world/2016/mar/08/recep-tayyip-erdogan-a-woman-isabove-all-else-a-mother-turkish-president (accessed 24 July 2020)

[13]_https://eurasianet.org/turkey-abortion-debate-dividing-already-split-society (accessed 24 July 2020)

[14]_https://www.independent.co.uk/news/world/europe/turkish-president-equality-betweenmen-and-women-is-against-nature-9879993.html (accessed 24 July 2020).

[15] https://artigercek.com/haberler/erdogan-elitler-ulkeye-asalak-gibiyapisti?t=1545425583\&fbclid=IwAR12Nfi7Y5h_Th70GIQ83LZzjqMC40d2LWgXK49tFStaS47kR6uxWARFqoCumhurba (accessed 27 July 2020) [16]_ https://www.aa.com.tr/tr/turkiye/cumhurbaskani-erdogan-islam-bize-gore-degil-bizislama-gore-hareket-edecegiz/1658026 (accessed 27 July 2020) 
[17] https://www.bbc.co.uk/news/world-europe-55901951 (accessed 13 February 2021) 